\title{
ANALISIS KANDUNGAN SEDIMEN DAN HARA TERANGKUT PADA DAS SUMPUR KABUPATEN TANAH DATAR
}

\author{
Yulnafatmawita, Amrizal Saidi, Aulia Rahman \\ Soil Science Laboratory Andalas University
}

\begin{abstract}
A study about sediment content and nutrient movement was conducted in Sumpur watershed, Tanah Datar Regency, West Sumatra. The objective of the research was to determine sediment content and nutrient movement on Sumpur watershed and the relationship. Survey method by sampling water in joining river was employed to this research for sampling water. Water was sampled exactly after rain or at the time of river debit was maximum and without rain as a control. Water flowing into the river comes from several lad uses in the upper watershed. There were four types of land use found in the areas, those were forest, mixed garden, annual season crops, and rice field. Based on field observation it was found that there were two classes of soils there, Andisols and Inceptisols. The results of laboratory analyses showed that river current, soil consentration in river water, as well as sediment content were linearly correlated to rainfall amount. Positive linear correlation was also found between river debit and carried nutrients (N, P, K, Ca, Mg, Na) from the research area.
\end{abstract}

Keywords: watershed, rainfall, sediment carried, and nutrient carried

\section{PENDAHULUAN}

Sedimen dan hara terangkut pada suatu aliran sungai sangat tergantung pada pengelolaan lahan yang ada di hulunya. Bila manusia, yang berperan sebagai pengelola, tidak memperhatikan kaidah konservasi dalam mengusahakan suatu daerah aliran sungai (DAS $=$ watershed) maka akan timbul dampak negative terhadap faktor ekologi baik pada lingkungan itu sendiri maupun pada lingkungan perairan di bawahnya. Daerah aliran sungai merupakan suatu kesatuan yang harus dikelola dengan baik agar tidak memberikan mudarat bagi kehidupan manusia dan makhluk hidup lainnya yang ada di daerah tersebut.

Sedimentasi adalah proses pengendapan bahan hasil erosi yang terbawa oleh aliran sungai, kemudian diendapkan pada suatu tempat sewaktu kecepatan air melambat dan akhirnya berhenti, atau masuk kedalam sungai, saluran, danau atau waduk. Sedangkan yang dimaksud dengan sedimen adalah tanah dan bagian-bagiannya yang terangkut dari suatu tempat ke tempat lain saat terjadi erosi (Arsyad, 1989). Sedimen umumnya mengendap di bagian bawah kaki bukit, di daerah genangan banjir, di saluran air, di sungai dan di waduk (Asdak, 1995).
Perbandingan antara jumlah sedimen yang betul-betul terbawa oleh aliran sungai suatu daerah terhadap jumlah tanah yang tererosi dari daerah tersebut disebut Nisbah Pelepasan Sedimen $\{$ NPS $=$ Sediment Delivery Ratio (SDR)\}. Nilai NPS berkisar $0-1$, bila nilai NPS mendekati 1 artinya semua tanah yang tererosi masuk kedalam sungai dan nilai NPS mendekati 0 artinya semua tanah yang tererosi tidak masuk kedalam sungai (Arsyad, 1976).

Robinson (1979 cit. Hilmar, 1991) mengemukakan beberapa faktor penting yang mempengaruhi jumlah sedimen yaitu luas dan tata guna lahan, topografi, sifat hujan dan aliran permukaan. Pada Tabel 1 dapat dilihat hubungan luas DAS dengan Sediment Delivery Ratio (SDR).

Dari Tabel 1 diatas dapat dilihat bahwa semakin luas areal suatu DAS maka SDR cendrung semakin rendah proporsinya dan sebaliknya dimana semakin sempitnya DAS maka semakin tinggi pula SDR.

Bentuk wilayah atau topografi berperan dalam menentukan kecepatan aliran air di permukaan yang membawa partikel-partikel tanah tersebut. Sedangkan peranan vegetasi penutup tanah adalah melindungi tanah dari pukulan langsung tetesan air hujan dan memperbaiki struktur tanah melalui penyebaran akar-akarnya. 
Tabel 1. Hubungan luas DAS dengan SDR

\begin{tabular}{cc}
\hline Luas DAS $\left(\mathrm{km}^{2}\right)$ & Sediment Delivery Ratio (\%) \\
\hline 0,1 & 53.0 \\
0,5 & 39,0 \\
1,0 & 35,0 \\
5,0 & 27,0 \\
10,0 & 24,0 \\
50,0 & 15,0 \\
100,0 & 13,0 \\
200,0 & 11,0 \\
500,0 & 8,5 \\
$26.000,0$ & 4,9
\end{tabular}

Sumber : Robinson (1979 cit.Hilmar, 1991)

Faktor kegiatan manusia memegang peranan yang sangat terutama dalam usahausaha pencegahan erosi, sebab manusia dapat memperlakukan faktor-faktor penyebab erosi lainnya, kecuali faktor iklim yang masih sulit diatasi (Sarief, 1985).

\section{Kehilangan Hara}

Kehilangan hara dari suatu lahan pertanian merupakan salah satu factor yang menyebabkan terjadinya penurunan produktifitas tanah karena erosi. Dalam proses erosi tanah yang terkikis dan terangkut adalah lapisan tanah atas yang merupakan sumber kehidupan tanaman karena umumnya pada lapisan ini tanaman memperoleh hara yang cukup. Kehilangan hara tanaman karena erosi pada lapisan tanah atas bisa mencapai, $\mathrm{N}=0,15$ persen, $\mathrm{P}$ $=0,01 \%$ dan $\mathrm{K}=0,2 \%$ (Saidi, 1995). Kehilangan tanah dan hara dari beberapa teras dalam usaha pertanian bisa dilihat pada Tabel 2.

Sirkulasi atau daur unsur hara yang berlangsung di suatu daerah aliran sungai seringkali digambarkan terjadi dalam satu dimensi: dari atmosfer ke vegetasi, dari vegetasi ke tanah dan dari tanah kembali lagi ke vegetasi. Bentuk daur yang demikian bersifat setempat. Seperti halnya dalam daur hidrologi, proses dan mekanisme daur unsure hara lazimnya berbentuk lingkaranlingkaran memanjang (spiraling cycle). Dalam hal ini lepasnya unsur hara dari wilayah tangkapan air (catchment area) ke sungai merupakan lepasnya unsur hara tersebut dari sistem ekologi setempat (Asdak, 1995).

Daerah Sumatra Barat yang bercurah hujan tinggi umumnya mempunyai topografi yang bergelombang dan berbukit atau mempunyai kelerengan yang curam ( $>15 \%)$, sehingga sangat peka terhadap erosi air. Hal ini sangat dirasakan bila daerah tersebut diusahakan untuk pertanian terutama tanaman semusim yang biasanya lahannya diolah secara intensif. Proses erosi oleh air ini akan mengikis tanah dari lahan pertanian dan mengalirkannya dipermukaan lalu mengendapkannya di bagian yang rendah, bahkan bisa lansung menuju sungai dan hanyut kebagian hilir. Hal ini bisa kita lihat dan buktikan yaitu dengan berubahnya debit dan warna air sungai saat atau beberapa waktu sesudah hujan. Bersamaan dengan hanyutnya tanah ini, unsur hara yang berada dalamnya juga ikut hilang ke bagian hilir. Dengan demikian kesuburan tanah akan menurun.

Penurunan kesuburan tanah akibat erosi sangat signifikan pada lahan pertanian yang diusahakan secara intensif, terutama pada pertanian tanaman semusim atau tanaman pangan.

Berdasarkan Yulnafatmawita et al (2003) pengolahan tanah yang intensif mengakibatkan aktifitas mikroorganisma meningkat karena terciptanya sirkulasi udara 
Tabel 2. Kehilangan tanah dan hara tanaman karena erosi oleh air hujan

\begin{tabular}{cccc}
\hline Kehilangan & $\begin{array}{c}\text { Jagung (teras } \\
\text { jagung bangku) }\end{array}$ & $\begin{array}{c}\text { Ubi kayu } \\
\text { (teras gulud) }\end{array}$ & $\begin{array}{c}\text { Kentang (tanpa } \\
\text { teras) }\end{array}$ \\
\hline $\begin{array}{c}\text { Tanah (ton/ha/th) } \\
\text { Bahan Organik }\end{array}$ & 4 & 16 & 80 \\
(kg/ha/th) & 150 & 600 & 3.000 \\
N (kg/ha/th) & 7,5 & 30 & 150 \\
P (kg/ha/th) & 5 & 20 & 100 \\
K (kg/ha/th) & 10 & 40 & 200 \\
\hline
\end{tabular}

Sumber : Utomo (1989 cit. Rahim, 2000)

dan kelembaban yang menunjang kehidupannya.

Mikroorganisma butuh bahan sebagai sumber makanan atau energinya, maka dengan demikian oksidasi bahan organik akan makin tinggi dengan pengolahan tanah. Akibatnya, kandungan bahan organik tanah akan menurun dengan waktu, bila tidak ada penambahan secara regular. Selanjutnya Yulnafatmawita et al (2007) melaporkan bahwa, ada penurunan kandungan OC tanah pada Andisol dengan perubahan ekologi hutan menjadi kebun campuran, tegalan dan sawah pada DAS Sumpur ini.

Daerah Aliran Sungai Sumpur merupakan salah satu DAS yang terdapat didaerah Sumpur Kecamatan Batipuh Kabupaten Tanah Datar. Berdasarkan peta jenis tanah, DAS Sumpur yang terletak antara $0^{\circ} 23^{\prime} 21.12^{\prime \prime}$ dan $0^{\circ} 34^{\prime} 22.8^{\prime \prime}$ LS serta antara $100^{\circ} 22^{\prime} 51.96^{\prime \prime}$ dan $100^{\circ} 29{ }^{\prime} 42^{\prime \prime}$ ini mempunyai 2 jenis tanah, yaitu Andisols dan Inceptisols. Daerah ini merupakan bagian dari Daerah Tangkapan Air (DTA) Danau Singkarak, atau airnya mengalir ke dananu Singkarak. Daerah Tangkapan Air danau Singkarak sangat berperan dalam mendukung keberadaan sumber daya alam maupun sumber daya manusia yang berada disekitar kawasan tersebut. Oleh sebab itu, pengawetan DAS Sumpur ini sangat diperlukan demi kesinambungan perannya bagi kesejahteraan penduduk di daerah tersebut dan di daerah hilirnya, bahkan untuk Sumatera Barat secara keseluruhan.

Akan tetapi, pada kenyataannya pengelolaan sumber daya alam pada DAS Sumpur ini tidak memperhatikan kaedah- kaedah konservasi lahan. Pada DAS Sumpur bagian hulu yang seharusnya dijadikan sebagai kawasan konservasi sudah dijadikan lahan pertanian. Seperti yang dilaporkan Yulnafatmawita et al (2007), daerah penelitian mempunyai 4 penggunaan lahan (hutan, sawah, kebun campuran, dan tegalan). Tambahan lagi, pengelolaan lahan yang dilaksanakan banyak menyalahi kaedah konservasi tanah dan air, diantaranya sawah pada daerah lereng terjal, ladang berpindah-pindah, dan pengolahan tanah yang tidak searah kontur. Hal tersebut telah menyebabkan perubahan beberapa sifat fisika tanah yang akan memicu timbulnya erosi di musim hujan dan kekeringan di musim kemarau.

Erosi, pengikisan tanah yang pada kawasan ini disebabkan oleh air, akan menghanyutkan tanah beserta unsur hara yang ada terkandung di dalamnya. Tanah dan unsur hara yang hanyut ini akan sampai ke sungai, yang bisa menyebabkan pencemaran air sungai. Air sungai yang digunakan lansung oleh penduduk untuk kebutuhan mereka sehari-hari menjadi menurun kualitasnya. Selanjutnya, tanah yang yang terkikis dari lahan di daerah hulu akan tersuspensi dalam air sungai dan mengendap pada bagian yang tenang, sehingga bisa menyebabkan pendangkalan sungai atau waduk, atau danau. Sedangkan unsur hara yang terlarut di dalam air sungai akan menyebabkan suburnya pertumbuhan gulma air, yang disebut dengan eutrophication. Eutropication ini lambat laun akan mematikan badan-badan air seperti sungai, waduk, maupun danau. Hal 
ini disebabkan oleh daur hidup gulma air yang pendek, yang dapat memproduksi bahan organik dan menimbunnya lansung di badan air, sehingga sungai atau waduk, ataupun danau tersebut menjadi semakin dangkal dan akhirnya mati.

Berangkat dari permasalahan yang dihadapi dan harapan terhadap DAS Sumpur ini, maka telah dilakukan penelitian yang bertujuan untuk menghitung kandungan sedimen dan hara terangkut pada DAS Sumpur Kabupaten Tanah Datar. Apakah tingkat sediment tersuspensi dan hara terangkut dari lahan pertanian ke sungai sudah melebihi batas kewajaran atau tidak. Hal ini sangat penting untuk memberikan masukan bagi pengambil kebijakan dalam pengelolaan lingkungan hidup. Peneluitian ini bertujuan untuk mengukur kandungan sediment dan kandungan hara terangkut pada DAS Sumpur serta hubungan antara jumlah curah hujan dengan debit sungai dan kandungan lumpur serta antara kandungan lumpur dan hara terangkut.

\section{BAHAN DAN METODA}

Penelitian ini dilaksanakan di lapangan (DAS Sumpur Bagian Hulu) dan di laboratorium (Fakultas Pertanian Unand). Penelitian lapangan dilakukan dalam dua tahap, yaitu (1) tahap persiapan dan survey pendahuluan (2) serta survai utama untuk pengambilan contoh tanah dan air sungai serta analisis di laboratorium.

Analisis tanah dan air dilakukan di Laboratorium Jurusan Tanah Fakultas Pertanian Universitas Andalas Limau Manis Padang. Pada tahap awal, data sekunder mengenai lokasi penelitian dikumpullkan. Data-data tersebut meliputi: peta jenis tanah, peta penggunaan tanah, peta topografi, dan peta titik-titik pengamatan. Survey pendahuluan dilakukan guna mengetahui keadaan lokasi penelitian dilapangan dan penetapan titik pengambilan sample air sungai.

Analisis sample air diantaranya: kandungan Lumpur, muatan sediment, kandungan hara N, P, K, Ca, Mg, dan Na. Di samping itu, data curah hujan, berapa kali hari hujan, dan berapa jumlah curah hujan juga diamati sebagai data penunjang. Kandungan lumpur dan muatan sediment dianalisis dengan metoda evaporasi. Sedangkan analisis hara $\mathrm{Na}$ dan $\mathrm{K}$ dengan flamephotometer, NO3- dan PO42- dengan calorimeter, Ca dan Mg dengan AAS (Pusat Penelitian Tanah Bogor , 1989).

\section{HASIL DAN PEMBAHASAN}

Hasil analisis kandungan lumpur, muatan sediment, dan kandungan hara terangkut dalam air sungai di daerah Sumpur Kabupaten Tanah Datar ditampilkan pada Tabel 1. Dari Tabel 1 terlihat bahwa peningkatan curah hujan meningkatkan debit sungai, kandungan Lumpur, dan muatan sediment. Curah hujan sebanyak $30 \mathrm{~mm}$ telah meningkatkan debit sungai sampai 805\%, kandungan Lumpur sebanyak 466\%, dan muatan sediment sebanyak 482\% dibanding pada kondisi normal atau saat hari tidak hujan. Berdasarkan Gambar 1, peningkatan curah hujan nyata meningkatkan debit sungai $\left(\mathrm{R}^{2}=0.99\right)$, kandungan Lumpur $\left(\mathrm{R}^{2}=0.96\right)$ dan muatan sediment $\left(R^{2}=0.94\right)$ secara linear.

Eratnya hubungan antara jumlah curah hujan dan debit sungai ini menggambarkan bahwa DAS Sumpur ini bagian hulunya sudah tidak berfungsi lagi sebagai regulator hidrologi. Tanahnya sudah hampir tidak menyimpan air hujan yang jatuh lagi yang bias dikeluarkan pada saat musim kemarau. Oleh sebab itu, daerah ini akan mengalami banjir saat hujan lebat dan akan kekeringan saat musim kemarau. Kondisi demikian sangat ditentukan oleh manajemen yang diberikan pada lahan pada DAS ini. Lahan yang dikelola tidak sesuai dengan kaedah konservasi, akan menyebabkan degradasi lahan daerah itu sendiri dan akhirnya degradasi lingkungan di daerah itu dan daerah hilirnya.

Air hujan yang jatuh di DAS Sumpur ini telah mengikis dan menghanyutkan bagian tanah. Hal ini terbukti peningkatan curah hujan meningkatkan kandungan lumpur serta muatan sediment. Lahan yang seharusnya dihutankan sudah dibuka, sehingga kanopi tanaman sudah sedikit lagi yang bisa mereduksi energi kinetik curah hujan menimpa permukaan tanah. Seperti yang disampaikan Yulnafatmawita et al (2003), jika energi kinetik input luar seperti curah hujan, bajak, injakan kaki binatang 
Tabel 1. Jumlah curah hujan, debit sungai, kandungan lumpur, dan hara terangkut pada DAS Sumpur

\begin{tabular}{|c|c|c|c|c|c|c|c|c|c|c|}
\hline \multirow{2}{*}{$\begin{array}{c}\text { Kejadian } \\
\text { Hujan }\end{array}$} & \multirow{2}{*}{$\begin{array}{c}\text { Curah hujan } \\
\text { (mm) }\end{array}$} & \multirow{2}{*}{$\begin{array}{l}\text { Debit sungai } \\
\mathbf{M}^{3} \text { detik }^{-1}\end{array}$} & \multirow{2}{*}{$\begin{array}{l}\text { Kandungan } \\
\text { Lumpur } \\
\mathbf{M}^{3} \text { detik }^{-1}\end{array}$} & \multirow{2}{*}{$\begin{array}{l}\text { Muatan } \\
\text { Sedimen } \\
\text { Ton hari }^{-1}\end{array}$} & \multirow[b]{2}{*}{$\mathbf{N}$} & \multicolumn{4}{|c|}{ Kandungan Hara Terangkut } & \multirow[b]{2}{*}{$\mathbf{M g}$} \\
\hline & & & & & & $\mathbf{P}$ & $\mathbf{K}$ & $\mathrm{Na}$ & Ca & \\
\hline 1 & 0.0 & 1.02 & 1.087 & 0.489 & 1.087 & 0.489 & 0.620 & 0.860 & 0.133 & 0.316 \\
\hline 2 & 19.30 & 5.04 & 1.291 & 1.280 & 1.291 & 1.280 & 2.030 & 3.470 & 0.538 & 0.802 \\
\hline 3 & 17.40 & 4.75 & 1.236 & 1.381 & 1.236 & 1.381 & 1.860 & 3.010 & 0.441 & 0.713 \\
\hline 4 & 30.00 & 8.21 & 1.452 & 2.359 & 1.452 & 2.359 & 3.610 & 4.790 & 0.884 & 1.282 \\
\hline Total & 66.70 & 19.02 & 5.066 & 5.509 & 5.066 & 5.509 & 8.120 & 12.130 & 1.996 & 3.113 \\
\hline Rata-Rata & & & & & 1.267 & 1.377 & 2.030 & 3.033 & 0.499 & 0.778 \\
\hline
\end{tabular}




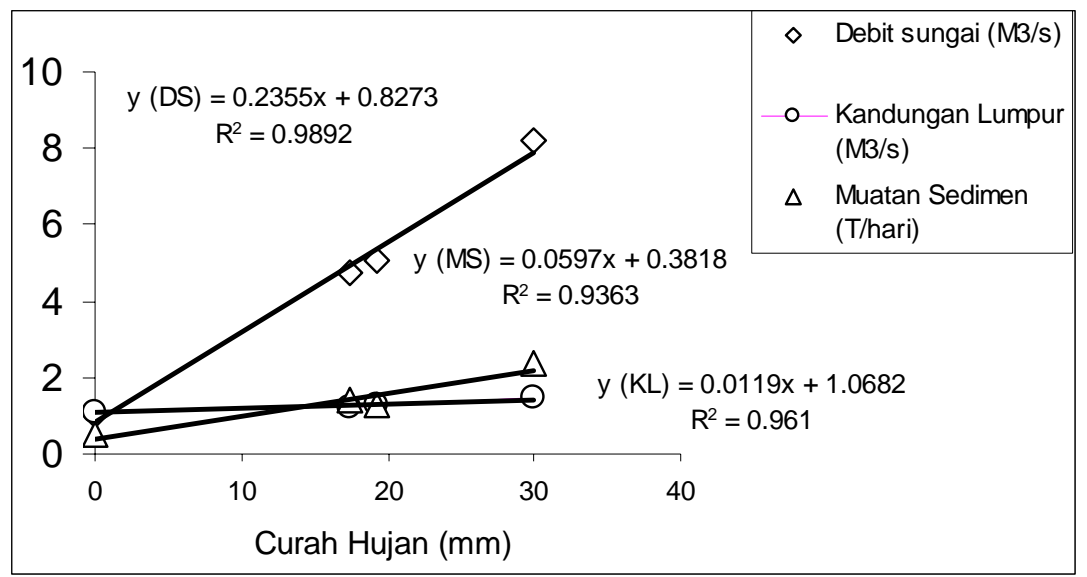

Gambar 1. Hubungan antara jumlah curah hujan dengan debit sungai, kandungan lumpur, dan muatan sedimen DAS Sumpur Kabupaten Tanah Datar

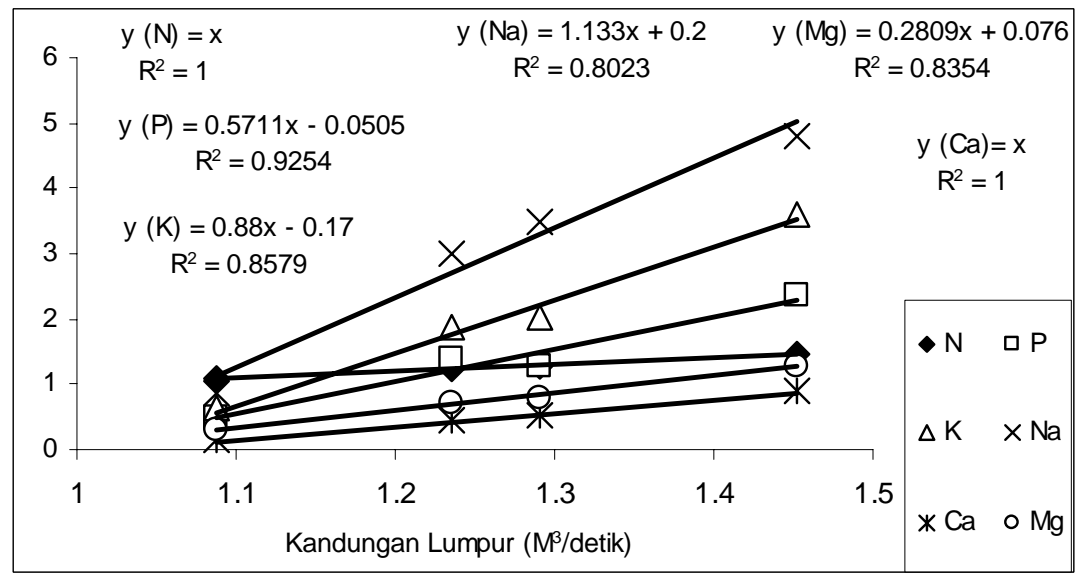

Gambar 1. Hubungan antara kandungan lumpur dan kandungan hara terangkut pada DAS Sumpur Kabupaten Tanah Datar

dan sebagainya lebih besar dari energi pengikatan butir tanah menjadi aggregat, maka aggregat tanah akan hancur. Pengolahan tanah yang berulang kali tanpa penambahan bahan amelioran tanah, ataupun jumlah dan intensitas curah hujan yang tinggi akan memecah aggregat menjadi lebih kecil bahkan bisa terdispersi menjadi butir tunggal tanah, seperti pasir, debu, dan liat. Partikel liat adalah butiran tanah yang paling kecil dan paling ringan, sehingga akan mudah tersuspensi oleh air hujan dan terbawa hanyut kebagian rendah dan bagian hilir. Atau dengan kata lain, tanah yang demikian sangat mudah mengalami erosi.
Tanah yang terserosi pada umumnya tanah yang berada pada permukaan tanah (sheet erosion) karena tanah ini lebih longgar, dan bahan organik pengikat dan pemantap aggregatnya sudah menipis akibat pengolahan yang intensif. Oleh sebab itu, tanah ini akan mudah terserosi. Tanah bagian permukaan, terutama pada lahan pertanian, akan mengandung sejumlah unsur hara yang tidak bisa terpisahkan dari tanahnya. Oleh sebab itu, ketika tanah ini terkikis dan hanyut (tererosi), maka unsur hara yang ada dalam lapisan tanah tersebut juga akan mengalami penghanyutan.

Berdasarkan Tabel 1, jumlah curah hujan mencapai $30 \mathrm{~mm}$ telah meningkatkan 
kandungan hara terangkut sebanyak 134\% (N), 482\% (P), 582\% (K), 557\% (Na), 665\% (Ca) dan 406\% (Mg) dibandingkan dengankondisi saat tidak hujan. Bila diperhatikan Gambar 2, maka terlihat bahwa peningkatan tersebut semuanya linear dengan koefisien determinasi yang tinggi. Peningkatan penghanyutan unsur hara $\mathrm{N}=$ $100 \%\left(\mathrm{R}^{2}=1\right), \mathrm{P}=93 \%\left(\mathrm{R}^{2}=0.93\right), \mathrm{K}=86 \%$ $\left(\mathrm{R}^{2}=0.86\right), \quad \mathrm{Ca}=100 \%\left(\mathrm{R}^{2}=1\right), \mathrm{Mg}=84 \%$ $\left(\mathrm{R}^{2}=0.84\right), \quad$ dan $\mathrm{Na}=80 \% \quad\left(\mathrm{R}^{2}=0.80\right)$ disebabkan oleh peningkatan kandungan lumpur dalam air sungai setelah hujan.

Tingginya koefisien determinasi dari masing-masing hubungan antara kandungan lumpur dan konsentrasi hara terangkut mengindikasikan bahwa tanah yang terserosi berasal dari lahan dengan kondisi kesuburan yang sama. Oleh sebab itu, semakin tinggi curah hujan semakin banyak jumlah tanah yang terserosi, sehingga semakin bayak pula jumlah hara yang hilang bersama tanah tersebut.

Jumlah hara yang hilang bersama air tanah saat tererosi ini bukan saja merugikan petani di DAS Sumpur ini, tetapi juga penduduk yang tinggal di hilir DAS. Hal ini disebabkan karena, bagi petani, lahannya terdegradasi dan efisiensi pemanfaatan pupuk oleh tanaman rendah, produksi menurun. Di samping itu, kondisi ini juga merugikan lingkungan daerah hilir, baik itu pemanfaatan sumber air secara lansung bagi kehidupan mereka maupun dampak negatif yang akan timbul (bencana alam) seperti banjir di musim hujan dan kekeringan di musim kemarau. Oleh sebab itu, penataan kembali DAS Sumpur terutama bagian hulunya sangat penting bagi kelestarian sumber daya alam dan lingkungan.

\section{KESIMPULAN}

Dari hasil analisis yang dilakukan terhadap debit sungai, kandungan lumpur, muatan sedimen dan kandungan hara terangkut pada air sungai pada beberapa kejadian hujan pada DAS Sumpur Bagian Hulu, maka dapat disimpulkan bahwa alih fungsi lahan dari ekologi hutan menjadi kebun campuran, tegalan, dan sawah secara umum telah memperlihatkan pengaruh yang nyata. Hal ini terbukti bahwa:
1. Peningkatan curah hujan telah meningkatkan debit sungai, kandungan lumpur, dan muatan sedimen secara liner. Demikian juga dengan peningkatan kandungan lumpur menigkatkan jumlah hara (N, P, K, Na, Ca, dan Mg) terangkut

2. Pada jumlah curah hujan $30 \mathrm{~mm}$ telah meningkatkan debit sungai sebanyak $800 \%$, kandungan lumpur sebanyak 466\%, dan kandungan sedimen sebanyak 482\% dibanding debit pada kondisi normal (hari tidak hujan)

3. Jumlah hara terangkut sebanding dengan jumlah kandungan lumpur pada air sungai. Peningkatan ini terlihat liner dengan $\mathrm{R}^{2}$ berkisar antara $0.8-1.0$.

\section{DAFTAR PUSTAKA}

Arsyad, S. 1989. Pengawetan Tanah dan Air. Departemen Ilmu Tanah Fakultas Pertanian IPB. Bogor.

Arsyad, S. 1976. Pengawetan Tanah dan Air. Departemen Ilmu Tanah Fakultas Pertanian IPB. Bogor.

Asdak, C. 1995. Hidrologi Dan Daerah Aliran Sungai. Gadjah Mada University Press. Yogyakarta.

Hilmar, F.D. 1991. Prediksi Erosi Dan Penilaian Besarnya Sedimentasi Daerah Aliran Sungai Kuranji Bagian Hulu Kodya Padang. Skripsi Fakultas Pertanian Universitas Andalas. Padang

Rahim, S.E. 2000. Pengendalian Erosi Tanah Dalam Rangka Pelestarian Lingkungan Hidup. Bumi Aksara. Jakarta.

Rusman, B. 1999. Konservasi Tanah dan Air. Fakultas Pertanian Universitas Andalas. Padang.

Saidi, A. 1995. Aliran Permukaan, Sedimentasi Serta Faktor-Faktor Yang Mempengaruhinya Serta Dampaknya Terhadap Degradasi Lahan Di Sub DAS Sumani Solok Sumatera Barat. Disertasi Pasca Sarjana Unpad. Bandung. 
Syarief, E.S. 1985. Konservasi Tanah dan Air. Pustaka Buana.

Yulnafatmawita, H.B. So, N. Menzies, and R.C. Dalal. 2003. $\mathrm{CO}_{2}$ emission from different soil fraction following physical disruption: Implication for tillage practices. Proceeding of the $16^{\text {th }}$ Triennial Int. Soil Tillage Res. Org. Brisbane Australia, July 2003.
Yulnafatmawita, Saidi, A., dan Rahman, A. 2007. Kajian Sifat Fisika Tanah DAS Sumpur Bagian Hulu Kabupaten Tanah Datar. J. Solum Vol IV No 1 